\title{
IMPELEMENTASI KONSEP MAKSIM DALAM MENILAI KEJUJURAN KOMUNIKASI ANTARA DOSEN DAN MAHASISWA
}

\author{
Zainul Muttaqin ${ }^{1}$, Herman Wijaya ${ }^{2}$, Muh. Taufiq ${ }^{3}$ \\ Program Studi Pendidikan Bahasa dan Sastra Indonesia Universitas Hamzanwadi ${ }^{1,2,3}$ \\ Pos-el: zainulmuttaqin@hamzanwadi.ac.id; wijaya.herman33@yahoo.com; \\ muhtaufiq27@yahoo.com
}

\begin{abstract}
This research uses quantitative and qualitative descriptive methods. The objectives of the research are (a) to know what maxims are violated by students and lecturers of Hamzanwadi University in communicating, (b) explain the implementation of Maksim concept in assessing the honesty of Lecturer and Student communication at Hamzanwadi University. The location of the research was conducted on the campus of Hamzanwadi University with the sample of research were 30 students and 3 lecturers. Data collection is done by using questionnaire, observation, and documentation. Data analysis techniques used in this study are descriptive statistics in the form of frequency distribution. The value of honesty data (beginning and end) is analyzed using T-Test type Paired Samples Test, while the data of honesty value using T-Test for each Independent Samples Test.

Based on the research results found that the maxim is often violated by lecturers and students PGSD in the verbal stage of the maxim quality and maxim way. Based on the normality test the level of honesty of PGSD Student communication with 0.56 rerate categorized "quite honest" in class $A, B$ da $C$ at the interval of the suspension 0.30-0.70. Based on the questionnaire of honesty of lecturer of MKU BI teaching in PGSD found different level of honesty that is 66,67\% elementary lecturer with index score interval of 0,67 which categorized "quite honest", then lecturer HY 80\% with index intervalskor 0,80 which is categorized as "honest", and dose NE 73.33\% with index score interval score of 0.73 which is "honest" with third rerate of lecturer is 73.33. Implementation of maxim concept of honesty value of communication between lecturers and students of PGSD on learning general course of Indonesia Language (BI) has fulfilled the principle of cooperation maxim with a fair degree of good honesty.

Keywords: Implementation, Maxim, Honesty Value, Communication,
\end{abstract}

Abstrak

Penelitian ini menggunakan metode deskriptif kuantitatif dan kualitatif. Tujuan penelitian yaitu (a) untuk mengetahui maksim apa saja yang dilanggar oleh mahasiswa dan dosen Universitas Hamzanwadi dalam berkomunikasi, (b) menjelaskan implementasi konsep Maksim dalam menilai kejujuran komunikasi Dosen dan Mahasiswa di Universitas Hamzanwadi.Lokasi penelitian dilakukan di kampus Universitas Hamzanwadi dengan sampel penelitian adalah 30 mahasiswa dan 3 dosen. Pengumpulan data dilakukan dengan menggunakan angket, observasi, dan dokumentasi. Teknik analisis data yang digunakan dalam penelitian ini statistik deskriptif dalam bentuk distribusi frekuensi. Data nilai kejujuran (awal dan akhir) dianalisis menggunakan T-Test tipe Paired Samples Test, sedangkan data nilai kejujuran menggunakan T-Tes tiap Independent Samples Test.

Berdasarkan hasil penelitian ditemukan bahwa maksim yang sering dilanggar oleh Dosen dan Mahasiswa PGSD pada tahap verbal yaitu maksim kualitas dan maksim cara. Berdasarkan uji Normalitas tingkat kejujuran komunikasi Mahasiswa PGSD dengan rerate 0,56 berkatagori "cukup jujur" pada kelas A,B da C pada interval skors 0,30-0,70. Berdasarkan sebaran angket kejujuran dosen MKU BI yang mengajar di PGSD ditemukan tingkat kejujuran yang berbedabeda yaitu dosen SD 66,67 \% dengan indeks interval skor 0,67 yang berkatagori "cukup jujur", 
kemudian dosen HY 80\% dengan indeks intervalskor 0,80 yang berkatagori "jujur", dan dose NE $73.33 \%$ dengan indeks interval skor 0,73 yang berkatagori "jujur" dengan rerate ketiga dosen yaitu 73.33. Implementasi konsep maksim nilai kejujuran komunikasi antara dosen dan mahasiswa PGSD pada pembelajaran MKU BI sudah memenuhi prinsip kerjasama maksim dengan tingkat kejujuran yang cukup baik.

Kata Kunci: Implentasi, Maksim, Nilai Kejujuran, Komunikasi,

\section{PENDAHULUAN}

Setidaknya ada tujuh krisis moral di tengah-tengah masyarakat Indonesia kekinian sebagaimana yang dikatakanAgustian (2008: 8-9) yaitu krisis kejujuran, krisis tanggung jawab, tidak berpikir jauh ke depan, krisis disiplin, krisis kebersamaan, krisis keadilan, krisis kepedulian. Hal tersebut senada dengan poin pendidikan karakter yang menyematkan enam nilai yaitu perilaku taat beribadah, sikap jujur, disiplin, tanggung jawab, peduli, dan kerja sama.

Jujur dalam pengertian yang baku yaitu mengakui, berkata atau memberikan suatu informasi yang sesuai kenyataan dan kebenaran. Dalam praktek dan penerapannya, kejujuran seseorang dinilai dari ketepatan pengakuan atau apa yang dibicarakan seseorang dengan kebenaran dan kenyataan yang terjadi. Bila berpatokan pada arti kata yang baku dan harafiah maka jika seseorang berkata tidak sesuai dengan kebenaran dan kenyataan atau tidak mengakui suatu hal sesuai yang sebenarnya, orang tersebut sudah dapat dianggap atau dinilai tidak jujur, menipu, mungkir berbohong, munafik atau lainnya (Somantri, 2011:78).

Ketidakjujuran dalam komunikasi verbal acap kali dipandang sebelah mata. Padahal ketidakjujuran pada ranah ini memiliki efek bola salju yang akan merebak ke ranah yang lebih besar (lingkungan sosial masyarakat). Jika persoalan tersebut terus saja dibiarkan, maka tidak menutup kemungkinan Mahasiswa atau Dosen menjadi peribadi yang cerdas namun manipulatif, cerdas tapi koruptif, cerdas tapi suka mengelabui teman, dan lain sebagainya.

Alasan lain kenapa kejujuran dalam komunikasi menjadi penting untuk dikaji yaitu berangkat dari beberapa penelitian tentang nilai kejujuran seperti membuat kantin kejujuran di kampus sebenarnya belum memberikan hasil maksimal. Kenapa?karena Dosen tidak tahu siapa Mahasiswa yang tidak jujur ketika hasil dagang tidak sama dengan barang yang habis terjual. Jika perkara tersebut berhenti hanya melihat hasil dagang, kemudian menyimpulkan bahwa ada Mahasiswa yang tidak jujur.Maka, hasil akhir penerapan nilai kejujuran tersebut belumlah maksimal karena Dosen tidak tahu siapa Mahasiswa yang tidak jujur tersebut.Oleh karena itu, untuk mengekseskusi langsung perkara di atas maka baiknya dilakukan penelitian kejujuran komunikasi. Dari penerapan kejujuran komunikasi inilah maka Dosen akan cepat mendeteksi siapa Mahasiswa yang tidak jujur.

Sebagaimana yang kita ketahui bahwa komunikasi sebagai media pengantar dalam proses belajar mengajar di dalam kelas memiliki urgensitas yang kuat. Pada umumnya komunikasiantara Dosen dan Mahasiswa selalu mempertimbangkan secara 
bersama-sama agar komunikasi yang dihasilkan tidak melanggar konsep Maksim.Ketika Dosen atau Mahasiswaberusaha membohongi, membingungkan, mempermainkan, ataumenyesatkan lawan bicara maka akanterjadi pelanggaran maksim dan poin kejujuran dalam pendidikan karaktertidak bisa terinternalisasi dengan baik.

Persoalan komunikasi di atas sangat erat dengan perspektif kajian pragmatik. Menurut Yule dalam Wijana (2009:3) menyatakan bahwa pragmatik studi makna (maksud) komunikasi antara penutur dan mitra tutur. Artinya bagaimana penutur melakukan penafsiran maksud dan makna terhadap tuturan mitra tutur. Kajian pragmatik terkait langsung dengan fungsi utama bahasa, yaitu sebagai alat komunikasi.Kajian pragmatik selalu terarah pada pemasalahan pemakaian bahasa di dalam suatu masyarakat bahasa, mengungkap bagaimana perilaku berbahasa suatu masyarakat bahasa bersosialisasi (Zamzani, 2007: 16).

Hal senada bisa dipahami bahwa pragmatik tidak hanya berbicara persoalan makna dan proses penafsiran tuturan akan tetapi lebih dari itu sebagaimana yang dikatakan Wijana (2004:47-49) bahwa pragmatik memperhatikan beberapa aspek penting dalam komunikasi yaitu penutur dan lawan tutur, konteks tuturan, tujuan tuturan, aktifitas tuturan, dan tuturan sebagai produk verbal.

Konsep maksim menitikberatkan kajiannya pada bagaimana penutur (Dosen) dan mitra tutur (Mahasiswa) mampu memberikan informasi yang secukupnya (Maksim Kuantitas), mampu memberikan informasi sebenarnya yang sesuai dengan fakta (Maksim Kualitas), memberikan informasi yang proporsional (Maksim Relevansi), memberikan informasi yang jelas dan tidak membingungkan (Maksim Cara)(Grice, 1991:164). Konsep maksim ini dipandang sangat tepat jika diterapkan untuk melihat sejauh mana poin kejujuran dalam pendidikan karakter itu bisa dijiwai atau diinternalisasikan oleh Mahasiswa dan Dosen dalam proses pembelajaran di kampus maupun dalam kehidupan sehari-hari mereka. Sebagai contoh dalam maksim kuantitas, seorang penutur diharapkan dapat memberikan informasi yang cukup, relatif memadai, dan seinformatif mungkin.Informasi demikian tidak boleh melebihi informasi yang sebenarnya dibutuhkan mitra tutur (Wijana, 2004:46-47). Hal senada juga terjadi pada maksim pelaksanaan dimana aspek yang ditekankan bukan mengenai apayang dikatakan, tetapi bagaimana cara mengungkapkan (Rahardi, 2005:57-580).

Adapun penelitian terdahulu yang cukup relevan dengan penelitian ini mengkaji tentang proses dampak pelanggaran maksim dalam proses perkuliahan adalah Ratna Susanti dengan judul penelitian "Pelanggaran Prinsip Kerjasama Dalm Proses Perkuliahan Di Politeknik Indonusa Surakarta" dalam Jurnal SAINSTECH Vol.3, Nomor 6 2016. Pada penelitian ini, Ratna fokus pada aspek maksim yang dilanggar dalam tuturan antara dosen dan mahasiswa pada mata kuliah Komunikasi Ilmiah. Adapun hasil dari penelitian Ratna yaitu terdapat tiga maksim yang dominan dilanggar yaitu maksim kualitas, kuantitas dan maksim relevansi.

Adapun letak beda penelitian Ratna dengan penelitian ini adalah pada aspek spesifikasi data. Pada penelitian ini peneliti memfokuskan pada data aspek kejujuran komunikasi antar dosen dan mahasiswa dalam proses perkuliahan Bahasa Indonesia. 
Kegelisahan dengan fenomena di atas membuat peneliti belum seutuhya melihat konsep pedidikan karakter pada poin kejujuran terinteralisasi dan menjadi habit Mahasiswadalam kehidupan sehari-sehari baik itu di kelas maupun di lingkungan sosial mereka. Persoalan di atas menjadi menarik ketika dikaji dengan konsep Maksim dalam bidang ilmu Pragmatik.

\section{METODE PENELITIAN}

Penelitian ini menggunakan dua tahap yakni tahap eksplorasi menggunakan metode deskriptif kuantitatif dan kualitatif dan pada tahap eksperimen menggunakan pendekatan kuantitatif. Penelitian ini membahas tentang maksim dalam menilai kejujuran komunikasi Dosen dan Mahasiswa di Universitas Hamzanwadi. Tujuan penelitian ini adalah (a) untuk mengetahui maksim apa saja yang dilanggar oleh mahasiswa dan dosen Universitas Hamzanwadi dalam berkomunikasi, (b) menjelaskan implementasi konsep Maksim dalam menilai kejujuran komunikasi Dosen dan Mahasiswa di Universitas Hamzanwadi.

Lokasi penelitian dilakukan di kampus Universitas Hamzanwadi dengan sampel penelitian adalah 30 mahasiswa dan 3 dosen yang masih terdaftar aktif di Universitas Hamzanwadi. Pengumpulan data dilakukan dengan menggunakan angket, observasi, dan dokumentasi. Teknik analisis data yang digunakan dalam penelitian ini yakni analisis angket yang diisi oleh Mahasiswa dan Dosen menggunakan statistik deskriptif yang kemudian disajikan dalam bentuk distribusi frekuensi. Setelah itu data dilihat dengan konsep maksim Grice (maksim kuantitas (maxim of quantity), maksim kualitas (maxim of quality), maksim relevansi (maxim of relevance), dan maksim pelaksanaan (maxim of manner)). Data kejujuran dari konsep maksim grice tersebut kemudian dianalisis menggunakan T-Test tipe Paired Samples Test, sedangkan data nilai kejujuran menggunakan T-Tes tiap Independent Samples Test.

\section{HASIL DAN PEMBAHASAN}

\section{Pelanggaran maksim dalam tuturan dosen dan mahasiswa PGSD Hamzanwadi}

Setelah melakukan observasi di dalam kelas.Peneliti menemukan ada dua (2) maksim yang dilanggar dalam komunikasi antara Dosen dan Mahasiswa PGSD yaitu Maksim Kualitas (Maxim of Quality) dan Maksim Cara (Maxim of Manner).

Mahasiswa: Bu, mana yang benar kata "resiko" atau "risiko"?

Dosen : Resiko anak-anak

Mahasiswa: Kemarin di TV saya melihat tulisannya "risiko", bu.

Dosen : Mungkin penulis beritanya salah ketik.

Mahasiswa: Oh, iya bu.

Dalam tuturan komunikasi di atas,Dosen telah melanggar maksim kualitas. Karakter kuat dalam maksim kualitas adalah seorangpeserta tutur diharapkan dapat 
menyampaikan sesuatu yang nyata dan sesuai faktasebenarnya di dalam bertutur.Fakta itu harus didukung dan didasarkan padabukti-bukti yang jelas.Pada kasus percakapan di atas Dosentidak memberikan jawaban yang sesuai dengan fakta yang sebenarnya dengan mengatakan bahwa kata yang benar adalah "resiko anak-anak" padahal dalam kamus besar Bahasa Indonesia, kata yang benar adalah "risiko". Pelanggaran maksim kualitas di atas menjadi indikator untuk menilai kejujuran seorang Dosen. Dalam percakapan di atas Dosen telah memberikan informasi yang salah dan tidak sesuai dengan fakta kebenaran.Selain itu jawaban Dosen "mungkin penulis beritanya salah ketik" menunjukkan bahwa Dosen berusaha menutupi ketidakmampuannya dengan cara menggunakan tuturan yang berputar-putar sehingga membuat Mahasiswa bingung.

Dosen : apakah kalian sudah hafal?

Mahasiswa: gak punya buku, bu.

Tuturan di atas memiliki kadar kejelasan yang rendah dan dengan sendirinya berdampak pada kekaburan makna atau maksud penutur. Tuturan Dosen sama sekali tidak memberikan kejelasan tentang apa yang sebenarnya dinginkan. Dengan demikian tuturan tersebut bisa ditafsirkan bermacam-macam. Demikian pula jawaban tuturan yang disampaikan Mahasiswa mengandung kadar ketidakjelasan yang cukup tinggi. Tuturan- tuturan demikian telah melanggar prinsip maksim cara dimana peserta tutur harus bertutur secara langsung, jelas, dan tidak ambigu.

Dosen : anak-anak, tema kita hari ini adalah puisi. Siapa yang sudah membaca buku bahasa Indonesia halaman 23 tentang puisi "Aku"?

Mahasiswa: saya bu

Dosen : coba kamu sebutkan siapa pengarang puisi tersebut?

Mahasiswa: Sutan Takdir Alisyahbana

Dosen : berarti Chairil Anwar yang menciptakan puisi "menuju ke laut dan perjuangn" ya?.

Dalam tuturan komunikasi di atas Mahasiswa telah melanggar maksim kualitas. Karakter kuat dalam maksim kualitas adalah, seorangpeserta tutur diharapkan dapat menyampaikan sesuatu yang nyata dan sesuai faktasebenarnya di dalam bertutur.Fakta itu harus didukung dan didasarkan padabukti-bukti yang jelas.Pada kasus percakapan di atas Mahasiswatidak memberikan jawaban yang sesuai dengan fakta yang sebenarnya dengan mengatakan bahwa pengarang puisi "Aku" adalah "Sutan Takdir Alisyahbana" padahal pengarang puisi tersebut adalah Chairil Anwar. Pelanggaran maksim kualitas di atas menjadi indikator untuk menilai kejujuran seorang Mahasiswa. Dalam percakapan di atas Mahasiswa telah memberikan informasi yang salah mengenai pengarang puisi "Aku".Kesalahan dan ketidakjujuran jawaban Mahasiswa di atas pada satu sisi telah membohongi Dosen dan teman kelasnya. 


\section{Implementasi konsep maksim dalam menilai kejujuran komunikasi antara Dosen dan Mahasiswa PGSD Universitas Hamzanwadi Selong. Analisis 1.Analisis data Angket Dosen:}

Pada bagian ini untuk memperkuat hasil kejujuran komunikasi antara Dosen dan Mahasiswa PGSD UNIVERSITAS Hamzanwadi Selong pada point 5.1., juga dilakukan crosscheck dengan menyebarkan angket kejujuran pada Dosen dan Mahasiswa. Adapun hasil dari implementasi konsep Maksim Grice pada tataran kejujuran komunikasi antara Dosen dan Mahasiswa PGSD UNIVERSITAS Hamzanwadi Selong berdasarkan penyebaran angket. Pada analisis angket Dosen, peneliti menemukan satu konsep maksim yang dilanggar yaitu maksim Kualitas, dengan total pelanggaran pada data angket sebanyak tiga (3) poin, sedangkan sisanya Dosen telah menerapkan konsep maksim dengan benar sebanyak sebelas (12) poin.

Apakah anda pernah bertanya tentang keadaan/kabar Mahasiswa sebelum pelajaran dimulai?

$\begin{array}{ll}\text { Dosen } & \text { : Ya } \\ \text { Mahasiswa } & : \text { Ya }\end{array}$

Dalam pertanyaan angket yang dibuat untuk Dosen pada pertanyaan nomor satu.Dosen memberikan jawaban "Ya". Pada tahap ini, untuk menilai kejujuran dan jenis maksim apa yang dilanggar belum bisa ditentukan. Oleh karena itu, peneliti melakukan crosscheck jawaban pada lembar angket Mahasiswa dengan pola pertanyaan yang sama. Adapun jawaban pada lembar jawaban angket Mahasiswa sama dengan Dosen yaitu "Ya". Dalam kasus ini setelah melakukan crosscheck jawaban baik itu pada lembar jawaban Dosen maupun Mahasiswa keduanya sama-sama melakukan yang sesuai dengan konsep Maksim. Dengan demikian yang menjadi indikator nilai kejujuran dijunjung tinggi pada poin pertanyaan nomor satu baik itu Dosen maupun Mahasiswa memberikan jawaban yang sama

Apakah anda pernah bertanya tentang kepahaman Mahasiswa terhadap pelajaran yang anda terangkan?

Dosen : Ya

Mahasiswa : Ya

Dalam pertanyaan angket yang dibuat untuk Dosen pada pertanyaan nomor dua.Dosen memberikan jawaban "Ya". Pada tahap ini, untuk menilai kejujuran dan jenis maksim apa yang dilanggar belum bisa ditentukan. Oleh karena itu, peneliti melakukan crosscheck jawaban pada lembar angket Mahasiswa dengan pola pertanyaan yang sama. Adapun jawaban pada lembar jawaban angket Mahasiswa sama dengan Dosen yaitu "Ya". Dalam kasus ini setelah melakukan crosscheck jawaban baik itu pada lembar jawaban Dosen maupun Mahasiswa keduanya sama-sama melakukan yang sesuai dengan konsep Maksim. Dengan demikian yang menjadi indikator nilai kejujuran dijunjung tinggi pada poin pertanyaan nomor dua baik itu Dosen maupun Mahasiswa memberikan jawaban yang sama. 
Apakah anda paham setiap materi pelajaran yang anda sampaikan pada Mahasiswa?

$$
\begin{array}{ll}
\text { Dosen } & \text { :Ya } \\
\text { Mahasiswa } & : \text { Ya }
\end{array}
$$

Dalam pertanyaan angket yang dibuat untuk Dosen pada pertanyaan nomor tiga.Dosen memberikan jawaban "Ya". Pada tahap ini, untuk menilai kejujuran dan jenis maksim apa yang dilanggar belum bisa ditentukan. Oleh karena itu, peneliti melakukan crosscheck jawaban pada lembar angket Mahasiswa dengan pola pertanyaan yang sama. Adapun jawaban pada lembar jawaban angket Mahasiswa sama dengan Dosen yaitu "Ya". Dalam kasus ini setelah melakukan crosscheck jawaban baik itu pada lembar jawaban Dosen maupun Mahasiswa keduanya sama-sama melakukan yang sesuai dengan konsep Maksim. Dengan demikian yang menjadi indikator nilai kejujuran dijunjung tinggi pada poin pertanyaan nomor tiga baik itu Dosen maupun Mahasiswa memberikan jawaban yang sama.

Apakah anda pernah mengulangi penjelasan ketika Mahasiswa anda kurang paham terhadap materi pelajaran?

$\begin{array}{ll}\text { Dosen } & \text { : Ya } \\ \text { Mahasiswa } & \text { : Tidak }\end{array}$

Dalam pertanyaan angket yang dibuat untuk Dosen pada pertanyaan nomor empat.Dosen memberikan jawaban "Ya". Pada tahap ini, untuk menilai kejujuran dan jenis maksim apa yang dilanggar belum bisa ditentukan. Oleh karena itu, peneliti melakukan crosscheck jawaban pada lembar angket Mahasiswa dengan pola pertanyaan yang sama. Namun pada lembar jawaban angket Mahasiswa justru jawabannya "Tidak" berbanding terbalik dengan jawaban Dosen pada angket Dosen. Berangkat dari jawaban Dosen pada data angket tersebut, dan jawaban angket Mahasiswa sebagai pembanding, maka Dosen sejatinya sudah melanggar Maksim Kualitas yaitu menyampaikan sesuatu yang nyata dan sesuai faktasebenarnya. Pada kasus angket Dosen di atas Dosentidak memberikan jawaban yang sesuai dengan fakta yang sebenarnya dilakukan pada Mahasiswa sebelum pelajaran dimulai.

Pelanggaran maksim kualitas di atas menjadi indikator untuk menilai kejujuran seorang Dosen. Jawaban Dosen di atas telah memberikan informasi yang salah dan tidak sesuai dengan fakta sebenarnya yang dilakukan. Selain itu jawaban Dosen pada lembar angket yang menyatakan " $Y a$ " menunjukkan bahwa Dosen berusaha membohongi dirinya sendiri juga membohongi Mahasiswa.

Apakah anda pernah memberikan kesempatan kepada Mahasiswa untuk bertanya tentang materi pelajaran yang telah anda ajarkan?

Dosen : : Ya

Mahasiswa : Ya

Dalam pertanyaan angket yang dibuat untuk Dosen pada pertanyaan nomor lima. Dosen memberikan jawaban "Ya". Pada tahap ini, untuk menilai kejujuran dan jenis maksim apa yang dilanggar belum bisa ditentukan. Oleh karena itu, peneliti melakukan crosscheck jawaban pada lembar angket Mahasiswa dengan pola pertanyaan yang sama. 
Adapun jawaban pada lembar jawaban angket Mahasiswa sama dengan Dosen yaitu "Ya". Dalam kasus ini setelah melakukan crosscheck jawaban baik itu pada lembar jawaban Dosen maupun Mahasiswa keduanya sama-sama melakukan yang sesuai dengan konsep Maksim. Dengan demikian yang menjadi indikator nilai kejujuran dijunjung tinggi pada poin pertanyaan nomor lima baik itu Dosen maupun Mahasiswa memberikan jawaban yang sama.

Apakah pendapat anda sering diabaikan oleh Mahasiswa?

Dosen : Tidak

Mahasiswa : Tidak

Dalam pertanyaan angket yang dibuat untuk Dosen pada pertanyaan nomor enam.Dosen memberikan jawaban "Tidak". Pada tahap ini, untuk menilai kejujuran dan jenis maksim apa yang dilanggar belum bisa ditentukan. Oleh karena itu, peneliti melakukan crosscheck jawaban pada lembar angket Mahasiswa dengan pola pertanyaan yang sama. Adapun jawaban pada lembar jawaban angket Mahasiswa sama dengan Dosen yaitu "Tidak". Dalam kasus ini setelah melakukan crosscheck jawaban baik itu pada lembar jawaban Dosen maupun Mahasiswa keduanya sama-sama melakukan yang sesuai dengan konsep Maksim. Dengan demikian yang menjadi indikator nilai kejujuran dijunjung tinggi pada poin pertanyaan nomor enam baik itu Dosen maupun Mahasiswa memberikan jawaban yang sama.

Ketika anda merasa kesulitan menjelaskan suatu pelajaran, apakah andatetap menjelaskan meskipun anda tidak mengerti?

Dosen : : Ya

Mahasiswa : Ya

Dalam pertanyaan angket yang dibuat untuk Dosen pada pertanyaan nomor tujuh.Dosen memberikan jawaban "Ya". Pada tahap ini, untuk menilai kejujuran dan jenis maksim apa yang dilanggar belum bisa ditentukan. Oleh karena itu, peneliti melakukan crosscheck jawaban pada lembar angket Mahasiswa dengan pola pertanyaan yang sedikit berbeda namun pada dasarnya substansinya sama yaitu "Ketika anda merasa kesulitan pada suatu pelajaran, apakah anda tetap mendengarkan penjelasan Dosen anda?". Adapun jawaban pada lembar jawaban angket Mahasiswa sama dengan Dosen yaitu "Ya". Dalam kasus ini setelah melakukan crosscheck jawaban baik itu pada lembar jawaban Dosen maupun Mahasiswa keduanya sama-sama melakukan yang sesuai dengan konsep Maksim. Dengan demikian yang menjadi indikator nilai kejujuran dijunjung tinggi pada poin pertanyaan nomor tujuh baik itu Dosen maupun Mahasiswa memberikan jawaban yang sama.

Apakah anda sering memberi apresiasi atas usaha keras Mahasiswa yang telah mengerjakan suatu tugas?

Dosen : Ya

Mahasiswa : Tidak

Dalam pertanyaan angket yang dibuat untuk Dosen pada pertanyaan nomor delapan.Dosen memberikan jawaban "Ya". Pada tahap ini, untuk menilai kejujuran dan jenis maksim apa yang dilanggar belum bisa ditentukan. Oleh karena itu, peneliti 
melakukan crosscheck jawaban pada lembar angket Mahasiswa dengan pola pertanyaan yang sama. Namun pada lembar jawaban angket Mahasiswa justru jawabannya "Tidak" berbanding terbalik dengan jawaban Dosen pada angket Dosen. Berangkat dari jawaban Dosen pada data angket tersebut, dan jawaban angket Mahasiswa sebagai pembanding, maka Dosen sejatinya sudah melanggar Maksim Kualitas yaitu menyampaikan sesuatu yang nyata dan sesuai faktasebenarnya. Pada kasus angket Dosen di atas Dosentidak memberikan jawaban yang sesuai dengan fakta yang sebenarnya dilakukan pada Mahasiswa sebelum pelajaran dimulai. Pelanggaran maksim kualitas di atas menjadi indikator untuk menilai kejujuran seorang Dosen. Jawaban Dosen di atas telah memberikan informasi yang salah dan tidak sesuai dengan fakta sebenarnya yang dilakukan.Selain itu jawaban Dosen pada lembar angket yang menyatakan " $Y a$ " menunjukkan bahwa Dosen berusaha membohongi dirinya sendiri juga membohongi Mahasiswa.

Apakah anda sering memberi pujian atas keberhasilan Mahasiswa menjawab pertanyaan anda?

Dosen : Ya

Mahasiswa : Ya

Dalam pertanyaan angket yang dibuat untuk Dosen pada pertanyaan nomor sembilan.Dosen memberikan jawaban "Ya". Pada tahap ini, untuk menilai kejujuran dan jenis maksim apa yang dilanggar belum bisa ditentukan. Oleh karena itu, peneliti melakukan crosscheck jawaban pada lembar angket Mahasiswa dengan pola pertanyaan yang sama. Adapun jawaban pada lembar jawaban angket Mahasiswa sama dengan Dosen yaitu "Ya". Dalam kasus ini setelah melakukan crosscheck jawaban baik itu pada lembar jawaban Dosen maupun Mahasiswa keduanya sama-sama melakukan yang sesuai dengan konsep Maksim. Dengan demikian yang menjadi indikator nilai kejujuran dijunjung tinggi pada poin pertanyaan nomor sembilan baik itu Dosen maupun Mahasiswa memberikan jawaban yang sama.

\section{Analisis 2. Analisis Data Angket Mahasiswa}

Pada analisis angket Mahasiswa, peneliti menemukan satu konsep maksim yang dilanggar yaitu maksim Kualitas, dengan total pelanggaran pada data angket sebanyak tiga (3) poin, sedangkan sisanya Mahasiswa telah menerapkan konsep maksim dengan benar sebanyak sebelas (12) poin.

Apakah Dosen pernah bertanya tentang keadaan/kabar anda sebelum pelajaran dimulai?

$\begin{array}{ll}\text { Mahasiswa } & : \text { Ya } \\ \text { Dosen } & : \text { Ya }\end{array}$

Dalam pertanyaan angket yang dibuat untuk Mahasiswa pada pertanyaan nomor satu.Mahasiswa memberikan jawaban "Ya". Pada tahap ini, untuk menilai kejujuran dan jenis maksim apa yang dilanggar belum bisa ditentukan. Oleh karena itu, peneliti melakukan crosscheck jawaban pada lembar angket Dosen dengan pola pertanyaan yang 
sama. Adapun jawaban pada lembar jawaban angket Dosen sama dengan Mahasiswa yaitu "Ya". Dalam kasus ini setelah melakukan crosscheck jawaban baik itu pada lembar jawaban Mahasiswa maupun Dosen keduanya sama-sama melakukan yang sesuai dengan konsep Maksim. Dengan demikian yang menjadi indikator nilai kejujuran dijunjung tinggi pada poin pertanyaan nomor satu baik itu Mahasiswa maupun Dosen memberikan jawaban yang sama.

Apakah Dosen pernah bertanya kepahaman anda terhadap pelajaran yang diterangkan?

Mahasiswa : Ya

Dosen : Ya

Dalam pertanyaan angket yang dibuat untuk Mahasiswa pada pertanyaan nomor dua.Mahasiswa memberikan jawaban "Ya". Pada tahap ini, untuk menilai kejujuran dan jenis maksim apa yang dilanggar belum bisa ditentukan. Oleh karena itu, peneliti melakukan crosscheck jawaban pada lembar angket Dosen dengan pola pertanyaan yang sama. Adapun jawaban pada lembar jawaban angket Dosen sama dengan Mahasiswa yaitu "Ya". Dalam kasus ini setelah melakukan crosscheck jawaban baik itu pada lembar jawaban Mahasiswa maupun Dosen keduanya sama-sama melakukan yang sesuai dengan konsep Maksim. Dengan demikian yang menjadi indikator nilai kejujuran dijunjung tinggi pada poin pertanyaan nomor dua baik itu Mahasiswa maupun Dosen memberikan jawaban yang sama.

Apakah anda paham setiap materi pelajaran yang disampaikan Dosen?

Mahasiswa : Ya

Dosen : Ya

Dalam pertanyaan angket yang dibuat untuk Mahasiswa pada pertanyaan nomor tiga.Mahasiswa memberikan jawaban "Ya". Pada tahap ini, untuk menilai kejujuran dan jenis maksim apa yang dilanggar belum bisa ditentukan. Oleh karena itu, peneliti melakukan crosscheck jawaban pada lembar angket Dosen dengan pola pertanyaan yang sama. Adapun jawaban pada lembar jawaban angket Mahasiswa sama dengan Dosen yaitu "Ya". Dalam kasus ini setelah melakukan crosscheck jawaban baik itu pada lembar jawaban Dosen maupun Mahasiswa keduanya sama-sama melakukan yang sesuai dengan konsep Maksim. Dengan demikian yang menjadi indikator nilai kejujuran dijunjung tinggi pada poin pertanyaan nomor tiga baik itu Mahasiswa maupun Dosen memberikan jawaban yang sama.

Apakah Dosen pernah mengulangi penjelasan ketika anda kurang paham terhadap materi pelajaran?

Mahasiswa : Tidak

Dosen : Ya

Dalam pertanyaan angket yang dibuat untuk Mahasiswa pada pertanyaan nomor empat.Mahasiswa memberikan jawaban "Tidak". Pada tahap ini, untuk menilai kejujuran dan jenis maksim apa yang dilanggar belum bisa ditentukan. Oleh karena itu, peneliti melakukan crosscheck jawaban pada lembar angket Dosen dengan pola pertanyaan yang sama. Namun pada lembar jawaban angket Dosen justru jawabannya 
SeBaSa: Jurnal Pendidikan Bahasa dan Sastra Indonesia

"Ya" berbanding terbalik dengan jawaban Mahasiswa pada angket Mahasiswa. Berangkat dari jawaban Mahasiswa pada data angket tersebut, dan jawaban angket Dosen sebagai pembanding, maka Mahasiswa sejatinya sudah melanggar Maksim Kualitas yaitumenyampaikan sesuatu yang nyata dan sesuai faktasebenarnya. Pada kasus angket Mahasiswa di atas Mahasiswatidak memberikan jawaban yang sesuai dengan fakta yang sebenarnya dilakukan oleh Dosen sebelum pelajaran dimulai. Pelanggaran maksim kualitas di atas menjadi indikator untuk menilai kejujuran seorang Mahasiswa. Jawaban Mahasiswa di atas telah memberikan informasi yang salah dan tidak sesuai dengan fakta sebenarnya yang dilakukan. Selain itu jawaban Mahasiswa pada lembar angket yang menyatakan "Tidak" menunjukkan bahwa Mahasiswa berusaha membohongi dirinya sendiri juga membohongi Dosen.

Apakah Dosen pernah memberikan kesempatan kepada anda untuk bertanya tentang materi pelajaran yang telah diajarkan?

$\begin{array}{ll}\text { Mahasiswa } & : \text { Ya } \\ \text { Dosen } & : \text { Ya }\end{array}$

Dalam pertanyaan angket yang dibuat untuk Mahasiswa pada pertanyaan nomor lima. Mahasiswa memberikan jawaban "Ya". Pada tahap ini, untuk menilai kejujuran dan jenis maksim apa yang dilanggar belum bisa ditentukan. Oleh karena itu, peneliti melakukan crosscheck jawaban pada lembar angket Dosen dengan pola pertanyaan yang sama. Adapun jawaban pada lembar jawaban angket Mahasiswa sama dengan Dosen yaitu "Ya". Dalam kasus ini setelah melakukan crosscheck jawaban baik itu pada lembar jawaban Mahasiswa maupun Dosen keduanya sama-sama melakukan yang sesuai dengan konsep Maksim. Dengan demikian yang menjadi indikator nilai kejujuran dijunjung tinggi pada poin pertanyaan nomor lima baik itu Mahasiswa maupun Dosen memberikan jawaban yang sama.

Apakah pendapat anda sering diabaikan oleh Dosen?

Mahasiswa : Tidak

Dosen : Tidak

Dalam pertanyaan angket yang dibuat untuk Mahasiswa pada pertanyaan nomor enam.Mahasiswa memberikan jawaban "Tidak". Pada tahap ini, untuk menilai kejujuran dan jenis maksim apa yang dilanggar belum bisa ditentukan. Oleh karena itu, peneliti melakukan crosscheck jawaban pada lembar angket Dosen dengan pola pertanyaan yang sama. Adapun jawaban pada lembar jawaban angket Mahasiswa sama dengan Dosen yaitu "Tidak". Dalam kasus ini setelah melakukan crosscheck jawaban baik itu pada lembar jawaban Mahasiswa maupun Dosen keduanya sama-sama melakukan yang sesuai dengan konsep Maksim. Dengan demikian yang menjadi indikator nilai kejujuran dijunjung tinggi pada poin pertanyaan nomor enam baik itu Mahasiswa maupun Dosen memberikan jawaban yang sama.

Ketika anda merasa kesulitan pada suatu pelajaran, apakah anda tetap mendengarkan penjelasan Dosen anda?

Mahasiswa : Ya

Dosen : :Ya 
Dalam pertanyaan angket yang dibuat untuk Mahasiswa pada pertanyaan nomor tujuh.Mahasiswa memberikan jawaban "Ya". Pada tahap ini, untuk menilai kejujuran dan jenis maksim apa yang dilanggar belum bisa ditentukan. Oleh karena itu, peneliti melakukan crosscheck jawaban pada lembar angket Dosen dengan pola pertanyaan yang sedikit berbeda namun pada dasarnya substansinya sama. Adapun jawaban pada lembar jawaban angket Mahasiswa sama dengan Dosen yaitu "Ya". Dalam kasus ini setelah melakukan crosscheck jawaban baik itu pada lembar jawaban Mahasiswa maupun Dosen keduanya sama-sama melakukan yang sesuai dengan konsep Maksim. Dengan demikian yang menjadi indikator nilai kejujuran dijunjung tinggi pada poin pertanyaan nomor tujuh baik itu Mahasiswa maupun Dosen memberikan jawaban yang sama.

Apakah Dosen anda sering memberi apresiasi atas usaha keras anda yang telah mengerjakan suatu tugas?

Mahasiswa : Tidak

Dosen : Ya

Dalam pertanyaan angket yang dibuat untuk Mahasiswa pada pertanyaan nomor delapan.Mahasiswa memberikan jawaban "Tidak". Pada tahap ini, untuk menilai kejujuran dan jenis maksim apa yang dilanggar belum bisa ditentukan. Oleh karena itu, peneliti melakukan crosscheck jawaban pada lembar angket Dosen dengan pola pertanyaan yang sama. Namun pada lembar jawaban angket Dosen justru jawabannya "Ya" berbanding terbalik dengan jawaban Mahasiswa pada angket Mahasiswa. Berangkat dari jawaban Mahasiswa pada data angket tersebut, dan jawaban angket Dosen sebagai pembanding, maka Mahasiswa sejatinya sudah melanggar Maksim Kualitas yaitu menyampaikan sesuatu yang nyata dan sesuai faktasebenarnya. Pada kasus angket Mahasiswa di atas Mahasiswatidak memberikan jawaban yang sesuai dengan fakta yang sebenarnya dilakukan oleh Dosen sebelum pelajaran dimulai. Pelanggaran maksim kualitas di atas menjadi indikator untuk menilai kejujuran seorang Mahasiswa. Jawaban Mahasiswa di atas telah memberikan informasi yang salah dan tidak sesuai dengan fakta sebenarnya yang dilakukan.Selain itu jawaban Mahasiswa pada lembar angket yang menyatakan "Tidak" menunjukkan bahwa Mahasiswa berusaha membohongi dirinya sendiri juga membohongi Dosen dan teman-temannya.

\section{Analisis data nilai kejujuran komunikasi antara Dosen dan Mahasiswa PGSD Universitas Hamzanwadi Uji Normalitas}

Teknik uji normalitas digunakan untuk menganalisis tingkat kejujuran komunikasi antara dosen dan mahasiswa pada taraf kepercayaan 5\%. Uji ini dilakukan untuk mengetahui sampel penelitian ini berasal dari populasi normal atau tidak serta sejauh mana tingkat kejujuran dosen dan mahasiswa tersebut.Bedasarkan hasil angket yang telah disebarkan pada dosen dan mahasiswa, maka hasil perhitungan uji normalitas data nilai tingkat kejujuran dosen dan mahasiswa dapat dilihat table di bawah ini. 
Tabel 3.

Uji Normalitas

\begin{tabular}{|c|c|c|c|c|c|}
\hline \multirow{2}{*}{ No } & \multirow{2}{*}{$\begin{array}{l}\text { Kelompok } \\
\text { Mahasiswa }\end{array}$} & \multirow{2}{*}{$\mathrm{N}$} & \multicolumn{2}{|c|}{ Harga Chi kuadrat } & \multirow{2}{*}{$\begin{array}{l}\text { Kesimpulan } \\
\text { berdistribusi }\end{array}$} \\
\hline & & & Hitung & Tabel & \\
\hline 1 & $\mathrm{~A}$ & 10 & 4,400 & 2,015 & Normal \\
\hline 2 & B & 10 & 3,000 & 2,353 & Normal \\
\hline 3 & $\mathrm{C}$ & 10 & 4,000 & 2,132 & Normal \\
\hline
\end{tabular}

Berdasarkan tebel di atas menunjukkan bahwa setiap kelompok kelas memiliki nilai yang berbeda-beda dan jumlah responden sebanyak 10 orang setiap kelas. Pada kelompok A nilai $\chi^{2}{ }_{\text {hitung }}$ sebesar 4, 400 dengan $\chi^{2}$ table 2, 015 dengan kriteria jika $\chi^{2}$ tabel $>\chi^{2}{ }_{\text {hitung }}$ maka data tersebut berdistribusi normal. Sedangkan kelompok B nilai $\chi^{2}$ hitungsebesar 3,000 dengan $\chi^{2}$ table 2,353 dengan kriteria normal karena $\chi^{2}$ hitunglebih besar dari pada $\chi^{2}$ table sehingga berkategori normal. Sementara pada kelomok $\mathrm{C}$ berkategori sama (normal) dengan kelompok kelas A dan B dengan nilai $\chi^{2}$ hitung sebesar 4, 000 dengan $\chi_{\text {table }}^{2}$, 132. Berdasarkan data tersebut dapat diambil kesimpulan bahwa data tersebut berkategori normal.

\section{Uji Homognitas}

Uji homogenitas bertujuan untuk mengetahui apakah antara ketiga kelompok sampel berasal dari populasi yang berdistribusi normal atau tidak maka dilakukan uji normalitas data. Kriteria pengujian dengan membandingkan ujiF $F_{\text {hitung }}$ denganF $_{\text {tabel }}$, kriteria pengambilan keputusan yaitu: bilaF $_{\text {hitung }}<\mathrm{F}_{\text {tabel }}$ maka data kedua kelompok adalah homogen dan sebaliknya bila $\mathrm{F}_{\text {hitung }}>\mathrm{F}_{\text {tabel }}$ maka kedua kelompok tersebut tidak homogen. Hasil perhitungan tingkat kejujuran komunikasi dosen dan mahasiswa secara ringkas ditunjukkan pada tabel berikut:

Table 4.

Uji Homogenitas

\begin{tabular}{|c|c|c|c|c|c|c|c|}
\hline No & Kelas & $\mathbf{N}$ & Varian & $\mathbf{F}_{\text {hitung }}$ & $\mathbf{F}_{\text {tabel }}$ & Rerata & Kategori \\
\hline 1 & $\mathrm{~A}$ & 10 & 7,156 & 0,387 & 5,79 & 0,56 & Cukup Jujur \\
\hline 2 & $\mathrm{~B}$ & 10 & 2,011 & 0,240 & 6,94 & 0,62 & Cukup Jujur \\
\hline 3 & $\mathrm{C}$ & 10 & 2,667 & 0,254 & 9,55 & 0,60 & Cukup jujur \\
\hline
\end{tabular}

Berdasarkan tabel di atas menunjukkan bahwa $F_{\text {hitung }}\left(F_{h}\right)$ yang diperoleh dari uji homogenitas varians dari angket yang telah disebarkandengan $\mathrm{N}_{1}=10, \mathrm{~N}_{2}=10$, dan $\mathrm{N}_{3}=$ 10. Berdasarkan hasil analisis angket yang telah dikumpulkan pada kelompok kelas $\mathrm{A}$ bahwaF hitung $=0,387$ lebih kecil dari $F_{\text {table }}=5,79$, maka kategori tingkat kejujuran komunikasi mahasiswa berdasarkan rumus yang telah ditetapkan pada bab IV berkategori "CukupJujur" dengan rerate 0,56. Sedangkan pada kelompok kelas B berdasarkan table di atas, bahwa $F_{\text {hitung }}=0,240$ lebih kecil dari $F_{\text {tebel }}=6,94$. Berdasarkan 
hasil hitungan tersebut maka tingkat kejujuran komunikasi mahasiswa kategori kelompok kelas B adalah berada pada posisi sama yakni "CukupJujur" dengan Rerate 0,62. Sementara kelas $\mathrm{C}$ tidak jauh berbeda hasilnya dengan kelompok kelas A dan B, dimana $\mathrm{F}$ hitung $=0,254$ lebih kecil dari $\mathrm{F}$ table $=9,55$, berdasarkan data ini tingkat kejujuran komunikasi mahasiswa berada pada kategori "CukupJujur" dengan rerate yang sama hampir sama dengan kelas yang lain yakni 0,60. Berdasarkan hasil analisis kelompok kelas, $\mathrm{A}, \mathrm{B}$, dan $\mathrm{C}$ menunjukkan bahwa $\mathrm{F}$ hitunglebih kecil dari $\mathrm{F}$ table, maka dapat diambil kesimpulan data tersebut Homogen.

Table 5.

Kategori Indeks kejujuran komunikasi Mahasiswa

\begin{tabular}{|l|l|}
\hline Interval Skor Indeks & Kualifikasi \\
\hline$<0.30$ & Kurang Jujur (KJ) \\
\hline $\mathbf{0 , 3 0 - 0 , 7 0}$ & Cukup Jujur $($ CJ) \\
\hline$>0,70$ & Jujur $($ J) \\
\hline
\end{tabular}

Sementara Dosen yang dijadikan respoden sebanyak tiga (3) orang.Masingmasing dosen mendapatkan angket kemudian diisi sesuai dengan petunjuk yang telah ditetapkan.Berdasarkan hasil uji angket tiga (3) dosen yang mengajar mata kuliah umum (MKU) Bahasa Indonesia di Prodi PGSD pada semester satu.

Mengacu pada hasil angket yang telah diisi oleh dosen dapat diketahui bahwa tingkat kejujuran komunikasi dengan mahasiswa memiliki tingkat yang berbeda-beda. Pada respoden pertama dengan inisial HSD nilai tingkat kejujuran komunikasi pada saat mengajar di kelas berdasarkan angket yang sudah disebarkan sebesar 66,67\%. Ini menunjukkan bahwa tingkat kejujuran responden tersebut berdasarkan rumus yang telah ditetapkan pada bab IV berada pada posisi "CukupJujur" dengan nilai indeks 0,67. Sedangkan responden kedua berinisial HY memiliki nilai tingkat kejujuran komunikasi pada saat mengajar di kelas sebesar 80,00\%, dengan nilai indeks 0,80. Ini menunjukkan bahwa tingkat kejujuran komunikasi responden HY berkategori "Jujur". Sementara nilai tingkat kejujuran komunikasi responden ketiga yang berinisial NE berdasarkan angket yang telah disebarkan sebesar $73,33 \%$ dengan nilai indeks 0,73 berkategori "Jujur". Bedasarkan data ketiga responden tersebut dapat diambil kesimpulan secara kolektif bahwa nilai tingkat kejujuran komunikasi dosen pada saat mengajar di kelas berkategori "Jujur" dengan nilai perkembangan 73,33.

Table 6.

Kategori Indeks kejujuran komunikasi Dosen

\begin{tabular}{|l|l|}
\hline Interval Skor Indeks & Kualifikasi \\
\hline$<0.30$ & Kurang Jujur (KJ) \\
\hline $0,30-0,70$ & Cukup Jujur (CJ) \\
\hline$>\mathbf{0 , 7 0}$ & Jujur $(\mathbf{J})$ \\
\hline
\end{tabular}




\section{SIMPULAN}

Berdasarkan pembahasan di atas bahwa maksim yang sering dilanggar oleh Dosen dan Mahasiswa PGSD pada tahap verbal yaitu maksim kualitas dan maksim cara dari empat maksim yang ditawarkan Grice. Berdasarkan angket yang disebarkan di kelas PGSD yang digunakan sebagai crosscheck data kejujuran komunikasi antara dosen da mahasiswa. Adapun maksim yang sering dilanggar oleh Dosen dan Mahasiswa PGSD yaitu maksim kualitas. Dari lima belas (15) butir soal kejujuran komunikasi yang disebarkan kepada tiga Dosen dan 30 Mahasiswa, tiga (3) dari butir angket melanggar konsep maksim, sedangkan dua belas (12) sudah memenuhi kualifikasi konsep maksim.

Berdasarkan uji Normalitas dengan menggunaakan SPSS v.17 maka tingkat kejujuran komunikasi Mahasiswa PGSD dengan rerate 0,56 berkatagori "cukup jujur" pada kelas A,B da C pada interval skors 0,30-0,70. Berdasarkan sebaran angket kejujuran dosen MKU BI yang mengajar di PGSD ditemukan tingkat kejujuran yang berbeda-beda yaitu dosen SD 66,67 \% dengan indeks interval skor 0,67 yang berkatagori "cukup jujur", kemudian dosen HY $80 \%$ dengan indeks intervalskor 0,80 yang berkatagori "jujur", dan dose NE $73.33 \%$ dengan indeks interval skor 0,73 yang berkatagori "jujur" dengan rerate ketiga dosen yaitu 73.33. Oleh sebab itu implementasi konsep maksim dalam menilai kejujuran komunikasi antara dosen dan mahasiswa PGSD pada proses pembelajaran MKU BI sudah memenuhi prinsip kerjasama maksim dengan tingkat kejujuran yang cukup baik.

\section{DAFTAR PUSTAKA}

Agustian, Ary Ginandjar. 2008. "Pembentukan Habit Menerapkan Nilai-nilai Religius, Sosial dan Akademik" dalamProceeding Seminar dan Lokakarya Nasional Restrukturisasi Pendidikan Karakter. Yogyakarta: Universitas Negeri Yogyakarta.

Grice, H. Paul. 1991. "Logic and Conversation," Paragmatics: A Reader, Davis S.(ed.). New York: Oxford University Press.

Rahardi, Kunjana. 2005. Sosiolinguistik (Kode dan Alih Kode)Yogyakarta : Pustaka Pelajar

Somantri, Endang. 2011. Pendidikan Karakter: Nilai Inti Bagi Upaya Pembinaan Kepribadian Bangsa. Bandung: Widya Aksara Press.

Susanti, Ratna. "Pelanggaran Prinsip Kerjasama Dalm Proses Perkuliahan Di Politeknik Indonusa Surakarta" dalam Jurnal SAINSTECH Vol.3, Nomor 6 2016. Diakses dari http://www.poltekindonusa.ac.id/wp-content/uploads/2017/05/Artikel7_Jurnal-Sainstech_Vol-3-Nomer-6-Desember-2106_Ratna-Susanti.pdf.

Wijana, I Dewa Putu. 2004. Dasar-Dasar Pragmatik. Yogyakarta: Andi.

Wijana, I Dewa Putu dan Muahammad Rahmadi. 2009. Analisis Wacana Pragmatik dan Kajian Teori dan Analisis. Surakarta: Yuma Pustaka.

Zamzani. 2007. Kajian Sosiopragmatik. Yogyakarta: Cipta Pustaka. 